\title{
ГІБРИДИЗАЦІЯ КОМПОНЕНТ У ТОНКИХ ГРАНУЛЬОВАНИХ ПЛІВКАХ НАНОКОМПОЗИТА $\mathrm{C}_{60}-\mathrm{Cu}$
}

\author{
О.П. ДМИТРЕНКО ${ }^{1}$ О.Л. ПАВЛЕНКО, ${ }^{1}$ М.П. КУЛІШ ${ }^{1}$ \\ М.А. ЗАБОЛОТНИЙ, ${ }^{1}$ М.Є. КОРНІЕНКО, ${ }^{1}$ В.А. БРУСЕНЦОВ, ${ }^{1}$ \\ В.М. РИБІЙ, ${ }^{1}$ Е.М. ШПІЛЕВСЬКИЙ ${ }^{2}$
}

${ }^{1}$ Київський національний університет ім. Тараса Шевченка, фізичний факультет (Вул. Володимирсъка, 64, Київ)

${ }^{2}$ Інститут тепло- та масообміну ім. А.В. Ликова

(Вул. П.Бровки, Мінсък, Білорусъ)

\begin{abstract}
Методом вакуумного співосадження атомів міді і молекул $\mathrm{C}_{60}$ одержано тонкі гранульовані плівки нанокомпозита $\mathrm{C}_{60}-\mathrm{Cu}$ із вмістом Cu 80 ат.\%, 34 ат.\% та 8 ат.\%. Ці плівки відпалювали при температурі $473 \mathrm{~K}$ протягом 10, 20, 30 годин у вакуумі. Для плівок з меншим вмістом атомів міді вже після осадження спостерігається різке зменшення відносної інтенсивності та розширення дипольно активної у раманівському розсіянні коливної моди $\mathrm{A}_{g}(2)$, чутливої до перенесення зарядів від атомів металу до $\mathrm{C}_{60} .3$ відпалом зменшення їі інтенсивності супроводжується зростанням інтенсивності і розширенням смуги коливної моди $\mathrm{H}_{g}(8)$. Крім того, з відпалом зростає інтенсивність триплетного випромінювання. Аналогічні процеси, але із запізненням, відбуваються у гранульованій плівці з більшим вмістом атомів міді. Трансформація спектрів коливань і фотолюмінесценції вказує на полімеризацію та руйнування молекул $\mathrm{C}_{60}$, яке відбувається за рахунок дифузї атомів міді з гранул у середовище $\mathrm{C}_{60} 3$ подальшим встановленням між ними хімічної взаємодії за рахунок перенесення зарядів від атомів металу до фулеренів.
\end{abstract}

\section{1. Вступ}

Молекули фулеренів, у тому числі найбільш поширені молекули $\mathrm{C}_{60}$ у конденсованому стані зберігають унікальні властивості, зумовлені їх геометрією і структурою. Такі незвичні для інших матеріалів властивості дозволяють їх широко використовувати для різноманітного застосування у наукоємних галузях техніки, енергозбереження, наноелектроніки та медицини.

Функціональні властивості фулеритів можуть бути значно розширені за рахунок фазових перетворень, які виникають в результаті зміни температури легування та зовнішньої дії. Одним із прикладів структурних змін у фулеритах є їх полімеризація, яка виникає внаслідок появи ковалентної взаємодії на заміну слабкого ван-дер-ваальсівського зв'язку між фулеренами, що притаманна фулеритам, які синтезовані при звичайних умовах. Полімеризований стан фулеритів достатньо просто одержати, застосовуючи їх стискання при температурах, значно вищих за кімнатні. Залежно від величини стискання і температури у стані фазової рівноваги у фулеритах $\mathrm{C}_{60}$ виникають різні структури як наслідок спотворення вихідної твердої фази з ГЦК-граткою, яка наявна при кімнатній температурі. Хімічний зв'язок типу [2+2]циклопід'єднання може виникати вздовж одного напрямку, найімовірніше, вздовж (001), тоді як у інших площинах ця взаємодія відсутня. Вибірковий характер міжмолекулярного [2+2]-циклопід'єднання також приводить до спотворення вихідної фази, виникає тетрагональна структура, для якої відстань між найближчими чотирма сусідніми молекулами зменшується. При більших величинах стиснення і температури з'являється ромбоедрична фаза як наслідок спотворення ГЦК структури у результаті появи сильної хімічної взаємодії між шістьма найближчими молекулами $\mathrm{C}_{60}$ у площині (111). Крім вказаних фаз можливою є поява димерів, а також стисненої ГЦК структури. В одержаних полімеризованих фазах спостерігається суттєва зміна електричних, оптичних, механічних, термодинамічних та інших властивостей [1-8]. Разом з тим необхідно відзначити, що 
вказаним способом полімеризовані фази можна одержати в об'ємних зразках $\mathrm{C}_{60}$.

Полімеризувати об'ємні фулерити $\mathrm{C}_{60}$ також можна шляхом їх легування лужними металами [9-17]. Легування стає можливим внаслідок низької енергії когезії атомів металу, що сприяє їх втіленню з газової фази у міжвузлові положення ГЦК структури. Залежно від числа атомів лужних металів, що приходиться на кожну молекулу $\mathrm{C}_{60}$ та розміщених в октаедричних і тетраедричних порах, можуть бути одержані проміжні структури та з'єднання $\mathrm{A}_{x} \mathrm{C}_{60}$ $(\mathrm{A}=\mathrm{K}, \mathrm{Rb}, \mathrm{Cs}$, де $x$ - число атомів на одну молекулу $\mathrm{C}_{60}$ ). Кожне зі з'єднань описується певною кристалічною структурою і характеризується своїм набором властивостей. Так, з'єднання $\mathrm{AC}_{60}$ та $\mathrm{A}_{3} \mathrm{C}_{60}$ мають металічну провідність, а з'єднання $\mathrm{A}_{4} \mathrm{C}_{60}, \mathrm{~A}_{6} \mathrm{C}_{60}$ є діелектриками. Хімічна взаємодія між молекулами встановлюється в результаті початкового виникнення кулонівської взаємодії між фулеренами і атомами металів внаслідок перенесення одного електрона до молекули $\mathrm{C}_{60}$ від атомів лужних металів. Таке перенесення заряду відбувається, оскільки лужні метали характеризуються низьким потенціалом іонізації, а молекули $\mathrm{C}_{60}$ - навпаки, великим значенням спорідненості до електронів.

Полімеризація плівок досягається також шляхом опромінення ультрафіолетовим світлом або бомбардуванням іонізуючими частинками ( $\gamma$-фотонами, електронами, іонами, нейтронами). Важливо, що від типу вибраного опромінення, енергії бомбардуючих частинок і дози не лише змінюються механізми полімеризації від [2+2]-циклопід'єднання [18-24] до структури типу "земляного горіха" [25-29], а можливим $\epsilon$ руйнування молекул $\mathrm{C}_{60} 3$ утворенням аморфного вуглецю $(\alpha-\mathrm{C})$. Залежно від співвідношення полімеризованої фази і аморфного вуглецю в опромінених зразках властивості одержаних матеріалів суттєво змінюються, що досягається шляхом впливу на співвідношення між ядерними та електронними втратами енергії іонізуючих частинок при їх взаємодії з фулеренами [30-35].

Особливе місце у зміні властивостей плівок $\mathrm{C}_{60}$ посідає їх легування нелужними металами. Для таких металів характерним є висока енергія когезії і низькі значення роботи виходу електронів. Саме тому залежно від методу легування можуть бути одержані зразки з гранульованими наночастинками $\mathrm{C}_{60}$ і металів або з атомами металів, втіленими у міжвузлові положення твердої фази $\mathrm{C}_{60}$. У кожному з цих випадків відбувається перенесення заряду від атомів металу до молекул $\mathrm{C}_{60}$ як через межу поділу фаз, так і з по- ложень втілення відповідно. Величина перенесеного заряду визначається, у першу чергу, типом металу, а також умовами одержання плівки. Гібридизація електронних станів молекул і атомів, а також заселення незайнятої молекулярної орбіталі (LUMO) фулеритів $\mathrm{C}_{60}$ приводить до суттєвої взаємодії між атомами та молекулами, а також впливає на транспортні, магнітні, електронні, оптичні, механічні та інші властивості одержаних композитів [36-39].

У даній роботі досліджуються оптичні властивості гранульованих тонких нанокомпозитів плівок $\mathrm{C}_{60} 3$ атомами міді залежно від вмісту міді та умов відпалу плівок $\mathrm{C}_{60}-\mathrm{Cu}$. Оптичні властивості вивчено при дослідженнях фотолюмінесценції та комбінаційного розсіяння світла (КРC).

\section{2. Методика експерименту}

Одношарові мідь-фулеренові $\left(\mathrm{C}_{60}-\mathrm{Cu}\right)$ плівки осаджували при одночасному випаровуванні у вакуумі атомів міді та сублімації молекул фулеренів $\mathrm{C}_{60} 3$ двох джерел. Плівки наносили на попередньо окислені пластини кремнію з орієнтацією поверхні (100). Різну концентрацію компонент одержували при зміні швидкості випаровування атомів міді. Для досліджень вибирали зразки із вмістом $\mathrm{Cu} 80$ ат.\%, 34 ат.\% та 8 ат.\%. Морфологію плівок вивчали за допомогою скануючої електронної мікроскопії, коливні та електронні спектри досліджували за допомогою КРС та фотолюмінесценції при використанні Ar лазера 3 довжиною хвилі збудження 514,5 нм, потужність якого не перевищувала 2 Вт/ $\mathrm{cm}^{2}$ для уникнення ефектів фотополімеризації.

\section{3. Результати експерименту і обговорення}

Дослідження плівок $\mathrm{C}_{60}$, осаджених на металічні підкладки методами рентгенівської фотоемісійної спектроскопії та високороздільної спектроскопії втрат енергї електронів [42], показують, що атоми підкладки, як і лужні атоми, передають молекулам $\mathrm{C}_{60}$ електрони, які заселяють LUMO і змінюють конфігурацію енергетичних станів НОМО та НОМО-1 [43]. Так, показано, що у випадку благородних металів перенесення заряду для $\mathrm{Cu}$ становить 1,8 електрона на одну молекулу $\mathrm{C}_{60}[44,45]$. Зміна зарядового стану $\mathrm{C}_{60}$ приводить до перерозподілу густини зарядів у LUM- та HOMO-зонах i, насамперед на одинарних i подвійних зв'язках між атомами вуглецю у цих молекулах. Як показують вимірювання із застосуванням скануючої тунельної мікроскопії [46], електрон- 


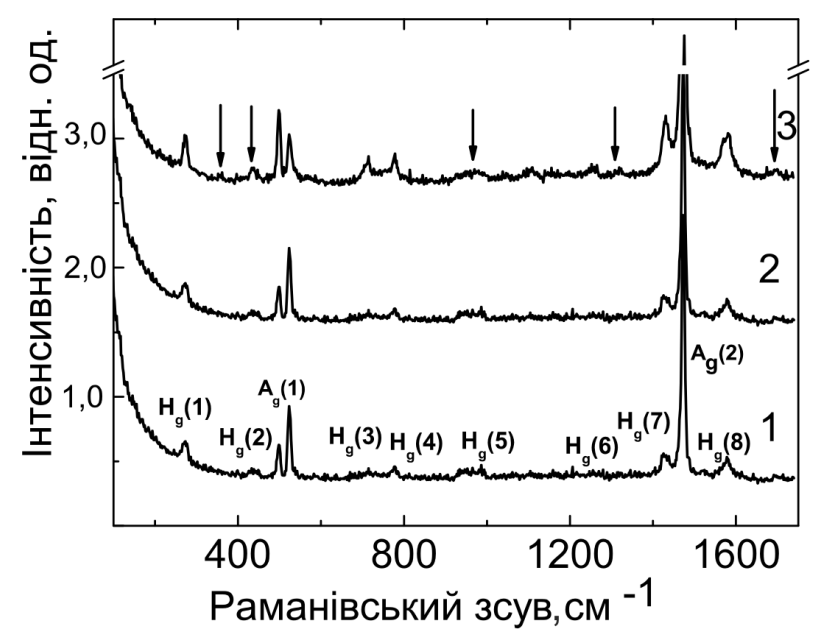

Рис. 1. Спектр раманівського розсіяння для гранульованих плівок $\mathrm{C}_{60}-\mathrm{Cu}$ із вмістом $\mathrm{Cu} 8$ ат.\%

ний стан LUMO-зони в основному локалізований на одинарних зв'язках пентагонів $\mathrm{C}_{60}$, а розподіл зарядів НОМО-зони переважно зосереджений на подвійних зв'язках гексагонів. Збільшення густини зарядів на подвійних та одинарних зв'язках приводить до зміни їх довжини, що проявляється у зміщеннях частот коливних мод, які чутливі до змін у довжинах зв'язків. Особливо сильно реагують на перенесення заряду тангенціальні коливні моди, наприклад, дипольноактивні у раманівському розсіянні $\mathrm{A}_{g}(2)$ та $\mathrm{H}_{g}(8)$, які знаходяться при більш високих частотах. Важливо, що зі збільшенням густини зарядів подвійні зв'язки розтягуються від довжини 1,39 до $1,43 \AA$, а одинарні зв'язки навпаки стягуються від довжини 1,45 до $1,43 \AA$, що приводить до зміщення частот у різні боки для тих коливних мод, у яких зайняті різні типи зв'язків. У тому випадку, коли мода визначається двома типами зв'язків, то внаслідок компенсації внеску різних зв'язків у зміщення реагує на перенесення заряду не суттєво.

Таким чином, на межі поділу $\mathrm{C}_{60}$-метал, як і у випадку розміщення атомів лужних металів в об'ємі $\mathrm{C}_{60}$, відбувається перенесення заряду від атомів металу до фулеренів, яке приводить до зміщення положень диполь-активних коливних мод. Так, у випадку легування твердих $\mathrm{C}_{60}$ лужними металами повносиметрична пентагональна пінч мода $\mathrm{A}_{g}(2)$ пом'якшується на $3 \mathrm{~cm}^{-1}$ при перенесенні на молекулу одного електрона. Для сполук $\mathrm{A}_{3} \mathrm{C}_{60}-\mathrm{A}_{6} \mathrm{C}_{60}$, у яких на фулерен, відповідно, переноситься 3 та 6 електронів, зміщення відбувається пропорційно [23, 24].

Аналогічна ситуація спостерігається на міжфазній межі фулерен-метал у гранульованих плівках, у яких величина перенесеного заряду і гібридизація електронних станів молекул $\mathrm{C}_{60} 3$ атомами металів у значно залежить від вмісту металу та умов осадження компонент. Відзначимо, що внаслідок значних величин енергії когезії нелужних металів спільне осадження молекул $\mathrm{C}_{60}$ і металів супроводжується утворенням гранульованих плівок, у яких, як правило, розміри гранул $\mathrm{C}_{60}$ та металів знаходяться у межах 10-50 нм. Обидва вказані фактори суттєво впливають на розміри гранул, які визначають дифузію атомів металу у гранули $\mathrm{C}_{60}$, а також розподіл електронів за енергетичними рівнями [49], що, у свою чергу, впливає на густину зарядів як у наногранулах фулеренів, так і у наногранулах металів.

На рис. 1 наведено спектр раманівського розсіяння для гранульованої плівки $\mathrm{C}_{60}-\mathrm{Cu} з$ вмістом $\mathrm{Cu}$ 80 ат.\%, 34 ат.\% та 8 ат.\%.

Як видно, для плівок $\mathrm{C}_{60}: \mathrm{Cu}$ спектр загалом збігається з виглядом аналогічного спектра для чистого $\mathrm{C}_{60}$, що характеризується двома повносиметричними коливними модами типу $\mathrm{A}_{g}(1-2)$ з частотами $497 \mathrm{i}$ $1469 \mathrm{~cm}^{-1}$ та вісьмома модами типу $\mathrm{H}_{g}(1-8)$ з частотами 270, 433, 709, 773, 1103, 1253, 1424, $1576 \mathrm{~cm}^{-1}$ [1]. Зі збільшенням числа атомів $\mathrm{Cu}$ на одну молекулу $\mathrm{C}_{60}$ спостерігається суттєве зменшення інтенсивності коливних мод $\mathrm{A}_{g}(1)$ та $\mathrm{A}_{g}(2)$, рис. 1, крива 2.

Разом із тим подальше збільшення вмісту атомів міді, коли вміст становить 80 ат.\%, приводить до вигляду спектра, який властивий чистому $\mathrm{C}_{60}$ [1]. Більше того, смуги всіх коливних мод підсилюються, і водночас з'являються додаткові смуги розсіяння поблизу положень $360,430,968,1318,1695 \mathrm{~cm}^{-1}$, рис. 1 , крива 3.

Очевидно, що при малій концентрації атомів міді кількість гранул металу незначна і атоми металу мало впливають на поведінку коливних мод фулеренів. Їх вплив поширюється лише на перший шар молекул, які створюють межу поділу метал- $\mathrm{C}_{60}$ [50]. Незважаючи на те, що у результаті перенесення заряду цей моношар може навіть ставати металічним внаслідок заповнення LUMO, незначна кількість молекул $\mathrm{C}_{60}$, гібридизованих з металічною поверхнею, як видно, не відіграє помітної ролі порівняно із загальною долею не взаємодіючих з металами фулеренів.

Водночас збільшення вмісту $\mathrm{Cu}$ приводить до більшої кількості гранул малих розмірів, що супроводжується появою великої кількості меж поділу, перенесення зарядів через які приводить до виникнення значної кількості молекул, що зв'язані з металами за рахунок іонної або донор-акцепторної взаємодії. На рис. 2 наведено розклад на можливі компоненти інтервалу 


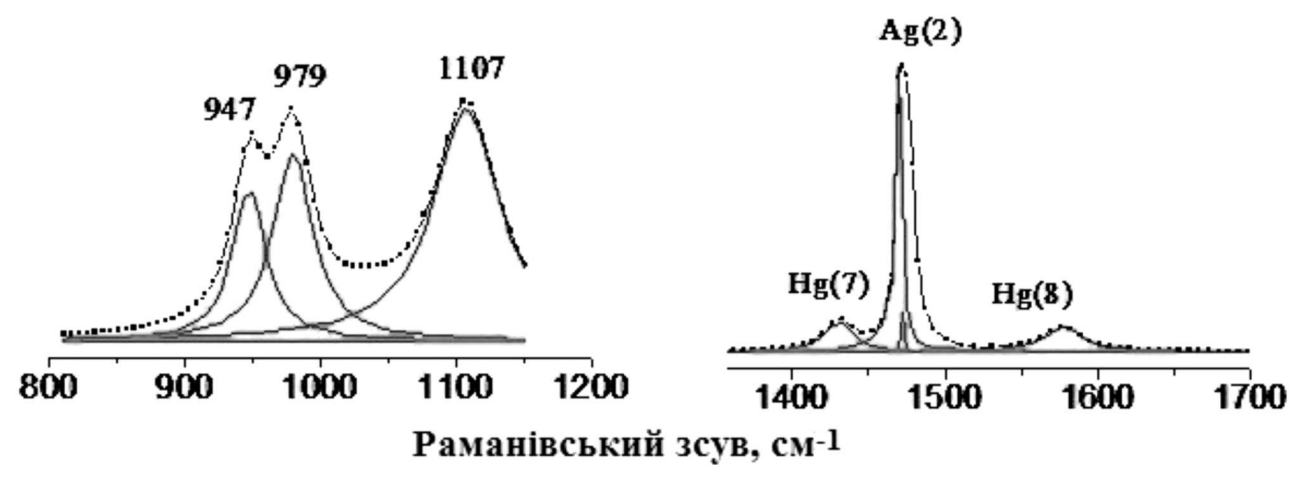

Рис. 2. Розклад на складові смуг коливних мод $\mathrm{Hg}(7), \mathrm{Ag}(2), \mathrm{Hg}(8)$ для плівки $\mathrm{C}_{60}-\mathrm{Cu}$ із вмістом $\mathrm{Cu} 34$ ат.\%

частот, у якому розміщені смуги коливних мод $\mathrm{H}_{g}(7)$, $\mathrm{H}_{g}(8), \mathrm{A}_{g}(2)$, що найбільш чутливі до перенесення заряду. Спостерігається не лише зменшення відносної інтенсивності лінії $\mathrm{A}_{g}(2)$, але і поява її компонент, що може бути наслідком зміщення цієї коливної моди в результаті перенесення заряду, а також полімеризації структури $\mathrm{C}_{60}$. Така полімеризація, що характеризується виникненням димерів, а, можливо, і більш складних фаз, є проявом часткової дифузії атомів $\mathrm{Cu}$ в область гранул $\mathrm{C}_{60}$ на стадії осадження. Не виключено, що вона більш властива ближчим до межі поділу фаз шарам як наслідок гібридизації молекул і атомів біля цієї поверхні. Механізмом міжмолекулярної взаємодії залишається, як і для інших випадків полімеризації, [2+2]-циклопід'єднання, яке викликане гібридизацією $s p$-станів фулерена і $d$-станів металів, що приводить до хімічної взаємодії між атомами металів і $\mathrm{C}_{60}$. Свідченням такої сильної взаємодії є значне падіння інтенсивності $A_{g}(2)$, яке стає можливим у випадку руйнування молекул, що спостерігається, наприклад, при високоенергетичному опроміненні 3 великими дозами [30]. Таке руйнування супроводжується зростанням інтенсивності в області коливної моди $\mathrm{H}_{g}(8)$, тобто в інтервалі тангенціальної коливної моди $\mathrm{E}_{g}$ аморфного вуглецю $(\alpha-\mathrm{C})$.

Зовсім іншим є вигляд спектра раманівського розсіяння для гранульованого композита з вмістом міді 80 ат.\%, який є результатом поверхневого підсилення раманівського розсіяння на молекулах $\mathrm{C}_{60}$. Таке підсилення можливе за рахунок утворення у матриці $\mathrm{C}_{60}$ таких розмірів гранульованих металічних наночастинок, які здатні за рахунок поверхневого плазмонного резонансу створювати локальні поля з великим значенням напруженості, взаємодія яких з розсіяними хвилями забезпечує помітне зростання інтенсивності смуг від усіх коливних мод. Спотворення молекул $\mathrm{C}_{60}$ внаслідок перенесення заряду незначне, що можливо, зв'язано з малою дифузією атомів міді від металічних гранул в об'єм матриці $\mathrm{C}_{60}$. Разом із тим, поява нових дипольно заборонених піків, зміщення раманівських смуг вказують на виникнення гібридизації молекул $\mathrm{C}_{60} 3$ атомами металу на межі поділу фаз, яка зумовлена перенесенням заряду.

Гранульовані частинки з їх розвиненою поверхнею подібно до металічних острівців, нанесених на поверхню $\mathrm{C}_{60}$ [49], сприяють дифузії атомів міді в об'єм $\mathrm{C}_{60}$. Як в аморфній матриці, так і в кристалічній фазі $\mathrm{C}_{60}$ дифундовані атоми міді займають енергетично найбільш вигідні положення (у кристалах - октаедричні та тетраедричні пори), з яких до молекул $\mathrm{C}_{60}$ відбувається перенесення заряду. Завдяки такому перенесенню заряду, як і для лужних металів, виникає хімічна взаємодія між лігандами і молекулами $\mathrm{C}_{60}$, яка, у свою чергу, сприяє виникненню міжмолекулярної взаємодії, що приводить до полімеризації, а, можливо, і до руйнування молекул $\mathrm{C}_{60}$.

Очевидно, що зростання дифузії атомів можна одержати внаслідок відпалу легованих плівок навіть при невеликих підвищених температурах, оскільки за значних розмірів міжмолекулярного простору енергія активації дифузії атомів металу є невисокою. На рис. 3 наведено зміну вигляду раманівських спектрів для нанокомпозита із вмістом міді 34 ат.\% при його відпалі протягом 10, 20, 30 год при температурі $473 \mathrm{~K}$.

Можна відзначити, що вже за 10 годин відпалу відбуваються чуттєві зміни спектра. Такі зміни спостерігаються у всій області спектра дипольно-дозволених коливних мод, а особливо в інтервалі коливних мод $\mathrm{H}_{g}(7), \mathrm{A}_{g}(2), \mathrm{H}_{g}(8)$, які найбільш чутливі до перенесення заряду та структурних змін, також і руйнування молекул $\mathrm{C}_{60}$ внаслідок сильної взаємодії з металами. Звертає на себе увагу підвищення зі зростанням часу відпалу 10 годин фону раманівського розсіяння в області тангенціальних мод. Крім того, мода $\mathrm{A}_{g}(2)$ 


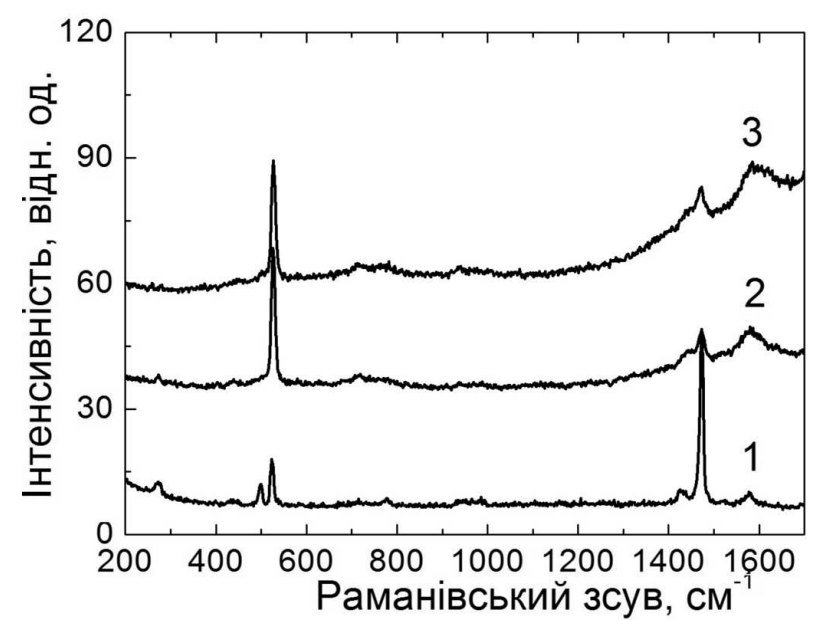

Рис. 3. Спектри раманівського розсіяння для плівок $\mathrm{C}_{60}-\mathrm{Cu}$ iз вмістом $\mathrm{Cu} 34$ ат.\%

сильно розширюється, майже повністю перекриваючись з модою $\mathrm{H}_{g}(7)$, а також спостерігається драматичне зменшення її інтенсивності до величин, за яких інтенсивність смуги $\mathrm{A}_{g}(2)$ стає не лише рівною інтенсивності піка $\mathrm{H}_{g}(8)$, а навіть стає меншою. Вказана перебудова спектра свідчить про сильне спотворення молекул $\mathrm{C}_{60}$, яке $є$ наслідком суттєвих змін густини зарядів на подвійних і одинарних зв'язках в фулеренах, які виникли в результаті перенесення заряду від атомів $\mathrm{Cu}$ до $\mathrm{C}_{60}$. Саме такі зміни густини зарядів в HOMO \& LUMO-станах впливають на розтягування подвійних і стискання одинарних зв'язків, які визначають симетрію молекул та, відповідно, поведінку коливного спектра. Варто відзначити, що дифузія атомів металу в матрицю $3 \mathrm{C}_{60}$ приводить не лише до руйнування молекул $\mathrm{C}_{60} 3$ утворенням $\alpha$-С фази, що проявляється в згасанні моди $\mathrm{A}_{g}(2)$ i зростанні інтенсивності моди $\mathrm{E}_{g}$ аморфного вуглецю, a і в більш складних структурних перетвореннях у фулеритах $\mathrm{C}_{60}$. Наявність таких перетворень видно з результатів розкладання смуг коливних мод $\mathrm{H}_{g}(7)$, $\mathrm{A}_{g}(2), \mathrm{H}_{g}(8)$ на компоненти при різних часах відпалу, див. рис. 4.

Водночас зміщені смуги, які відповідають димеризації та більш складним орторомбічній і іншим структурам, є малоінтенсивними. Швидше це є проявом неупорядкованого стану переважної частини молекул $\mathrm{C}_{60}$ в синтезованих гранулах плівок, в яких полімеризація лише частково обмежується утворенням димерів.

Подібні зміни також спостерігаються для зразка 3 великим вмістом металу $\mathrm{Cu} 80$ ат. \%, але більш уповільнено. Так, навіть при 20 год відпалу при темпера- турі $473 \mathrm{~K}$ картина підсиленого раманівського розсіяння зберігається і лише із збільшенням часу відпалу до 30 год спостерігається значне відносне падіння інтенсивності піків відносно смуги $\mathrm{H}_{g}(8)$, рис. 5 .

Можна припустити, що в таких зразках при більших розмірах гранул $\mathrm{Cu}$ велике значення енергії когезіі стримує дифузію атомів металу в гранули $\mathrm{C}_{60}$ i тому взаємодія між молекулами та атомами обмежується лише поблизу поверхні розподілу фаз. В об'ємі $\mathrm{C}_{60}$ внаслідок малого числа дифундованих атомів вплив на фулерени незначний, але він є і збільшується в разі зростання часу відпалу.

Очевидно, що у випадку зміни симетрії молекул $\mathrm{C}_{60}$ внаслідок перенесення на них заряду від атомів металів також трансформується спектр фотолюмінесценції. У випадку низьких температур (менше за $15 \mathrm{~K}$ ) спектр об'ємної люмінесценції кристалів $\mathrm{C}_{60} €$ результатом накладання двох смуг 3 центрами 734 нм i 684 нм [51]. Смуга при 734 нм являє собою широкосмугове свічення, яке зумовлено неоднорідно розширеними переходами з глибокої $X$-пастки. Ця пастка відповідає збуреному екситону Френкеля зі зниженою симетрією, делокалізованим у просторі між двома сусідніми молекулами, які розміщені поряд з вакансією у кристалі або поблизу з іншим дефектом, який вносить розупорядкування структури.

Смуга при 734 нм є також характерною для кристалів при кімнатних температурах. Вона виступає як високоенергетична смуга люмінесценції з максимумом при 1,69 еВ, яка зумовлена об'ємним випромінюванням фулерена. Дана смуга в області більш низьких енергій перекривається випромінюванням, яке викликане присутністю в твердих $\mathrm{C}_{60} X$-пасток. Такими пастками можуть бути дефекти фізичного або хімічного походження, що знаходяться на сусідньому 3 даною молекулою вузлі і $є$ причиною порушення трансляційної симетрії в гратці. У випадку полімеризації смуги випромінювання порівняно з неполімеризованим зразком зсувається в червону область і розширюється.

Для плівок фулеренів $\mathrm{C}_{60}$, у яких переважна частина молекул знаходиться в аморфному стані, з окремими вкрапленнями кристалічних наночастинок з розмірами $\sim 40$ нм, при кімнатній температурі люмінесценція вміщуе дві широкі безструктурні смуги випромінювання [52-55]. Одна з них високоенергетична, яка зосереджена поблизу енергії 1,69 еВ, відповідає флуоресценції, а інша низькоенергетична, що спостерігається біля положення $=1,4 \mathrm{eB}$, належить фосфоресценції $[53,56]$. У випадку полімеризації змінюється 

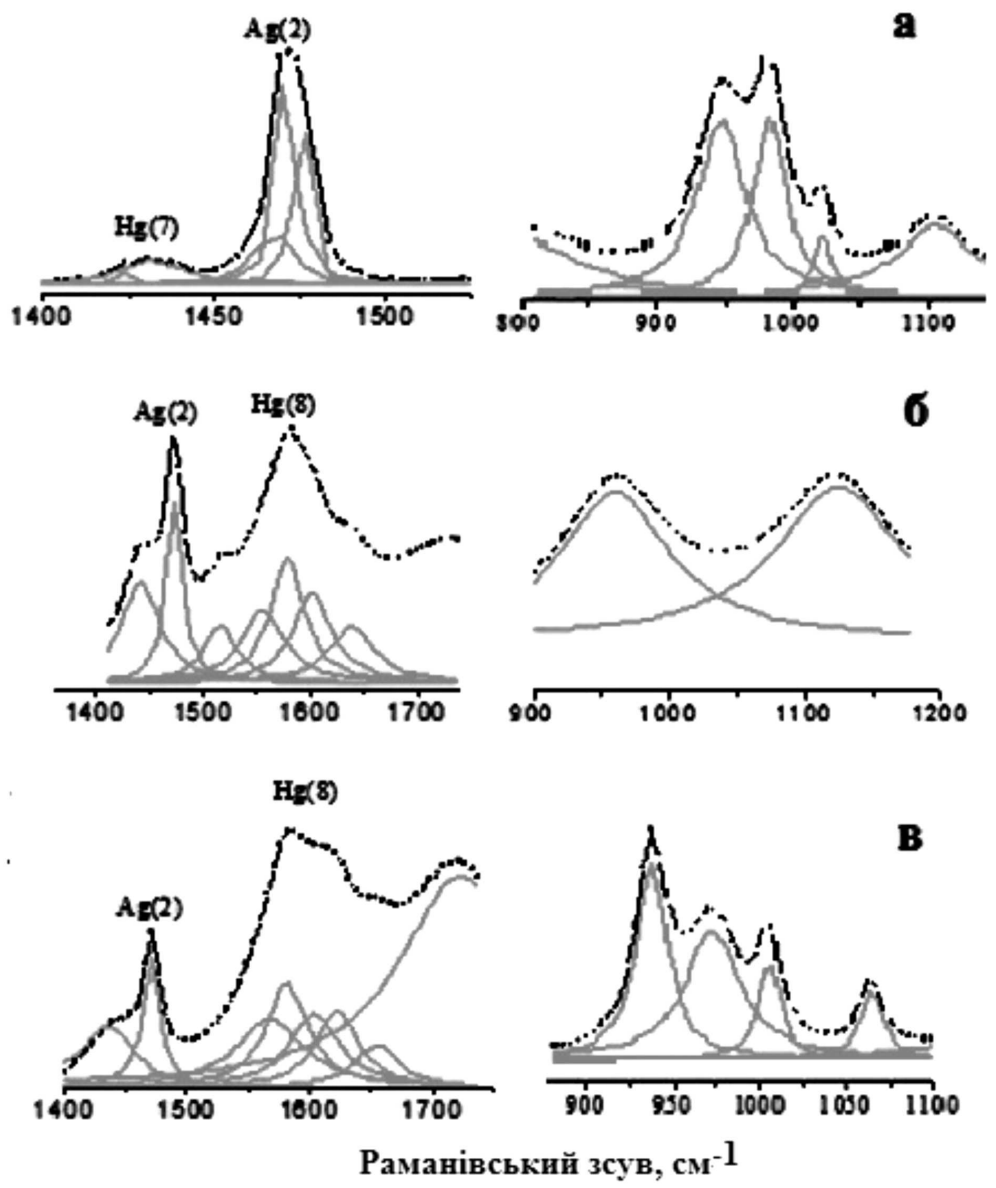

Рис. 4. Розклад на складові смуг коливних мод $\mathrm{Hg}(7), \mathrm{Ag}(2), \mathrm{Hg}(8)$ для плівки $\mathrm{C}_{60}-\mathrm{Cu}$ із вмістом $\mathrm{Cu} 34$ ат.\%

співвідношення інтенсивностей вказаних смуг. Воно є різним залежно від температур, за яких одержано спектри люмінесценції від плівки. Так, за низьких температур інтенсивність випромінювання низькоенергетичної смуги зростає із збільшенням ступеня полімеризації, що вказує на зростання кількості глибоких пасток або на збільшення квантового виходу триплетного випромінювання [54, 55]. Оскільки внаслідок полімеризації при утворенні димерів, тримерів, ланцюгів у результаті появи ковалентного зв'язку між молекулами відстань між молекулами і їх симетрія порівняно з неполімеризованим станом зменшується, то енергетичні рівні молекул знижуються. У зв'язку з цим у випадку полімеризації спостерігається розширення енергетичних рівнів фулеренів i, відповідно, локальних (дефектних) станів, що відповідають за емісію фулеренів.

На рис. 6 наведено спектр люмінесценції для плівки $\mathrm{C}_{60}-\mathrm{Cu} з$ вмістом міді $\mathrm{Cu} 34$ ат.\% після осадження

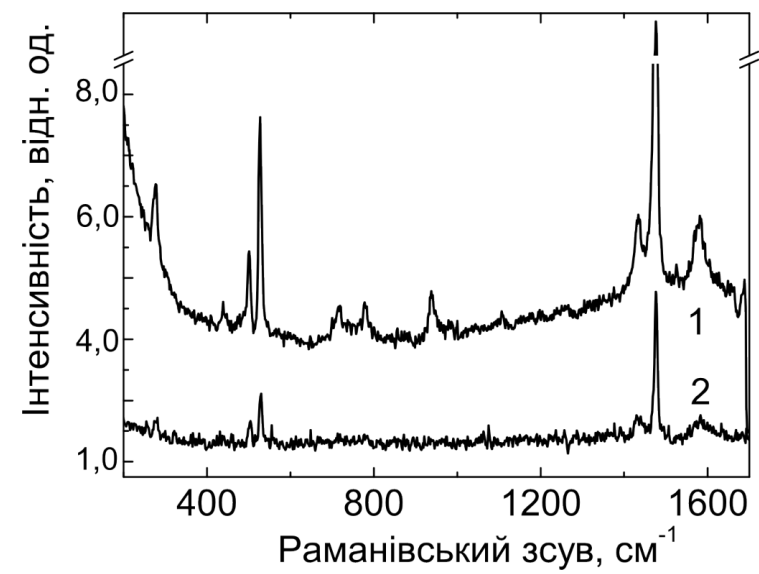

Рис. 5. Спектри раманівського розсіяння для плівок $\mathrm{C}_{60}-\mathrm{Cu}$ із вмістом Сu 80 ат.\%

та відпалу при температурі $473 \mathrm{~K}$ протягом 10, 20 i 30 год. 


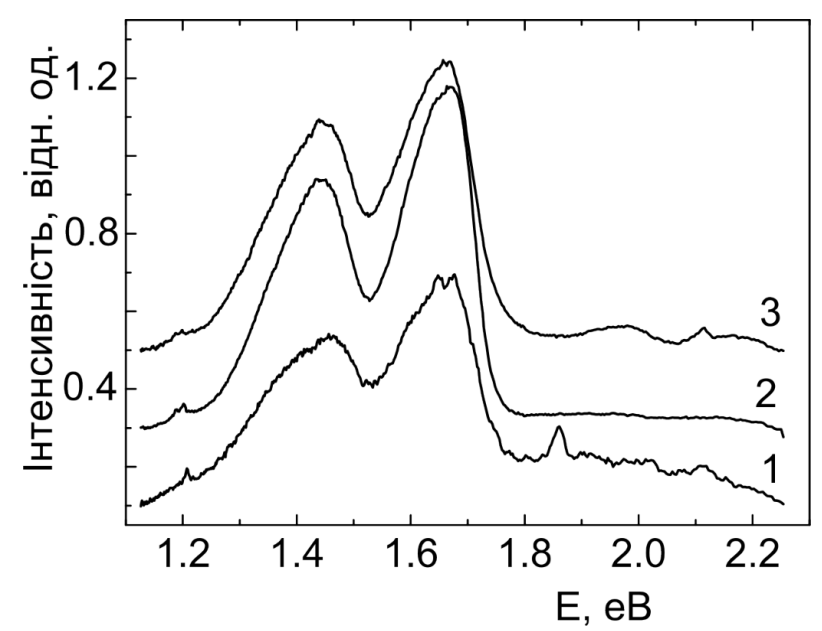

Рис. 6. Фотолюмінесценція для нанокомпозитних плівок $\mathrm{C}_{60}-$ $\mathrm{Cu}$ із вмістом $\mathrm{Cu} 34$ ат.\%

Видно, що спектр люмінесценції складається з двох широких безструктурних смуг. Як і при дослідженні інших подібних плівок, можна стверджувати, що високоенергетична смуга поблизу 1,69 еВ зумовлена флуоресцентним свіченням синглетних екситонів Френкеля, захоплених глибокою $X$-пасткою, якою виступає спотворена молекула $\mathrm{C}_{60}$ у присутності ваканciї або атома $\mathrm{Cu}$, що продифундував у матрицю $\mathrm{C}_{60} 3$ нанорозмірних гранул металу, або у процесі осадження плівки. Друга широка смуга з'являється в результаті переходу з триплетного стану молекул. Великий квантовий вихід триплетного свічення вказує на те, що значна кількість молекул внаслідок інтеркомбінаційного переходу знаходиться у триплетному стані. Відомо, що перехід молекул до триплетного стану сприяе утворенню комплексів, а також зв'язуванню їх між собою за рахунок ковалентного зв'язку. Крім того, на відміну від плівок чистих $\mathrm{C}_{60}$ обидві смуги дуже розширені, що вказує на полімеризацію, яка сприяє розкиду енергетичних рівнів фулерена. При цьому механізм полімеризаціі, можливо, дещо менше зумовлений виникненням $[2+2]$-циклопід'єднання між молекулами, а більше зв'язаний з виникненням хімічної взаємодії атомів $\mathrm{Cu} з$ двома сусідніми фулеренами. Такий зв'язок породжує, в першу чергу, димери, в яких атоми міді знаходяться між молекулами, а також не виключена поява ланцюгових структур.

Відпал зразка протягом 10 і 20 год (рис. 6, криві 2 і 3 ) приводить до відносного зростання випромінювання, зв'язаного з триплетним станом. Фосфоросценція ще більше зростає для плівки відпаленої протягом 30 годин, і величина інтегральної інтенсивності стає майже однаковою з аналогічним значенням для

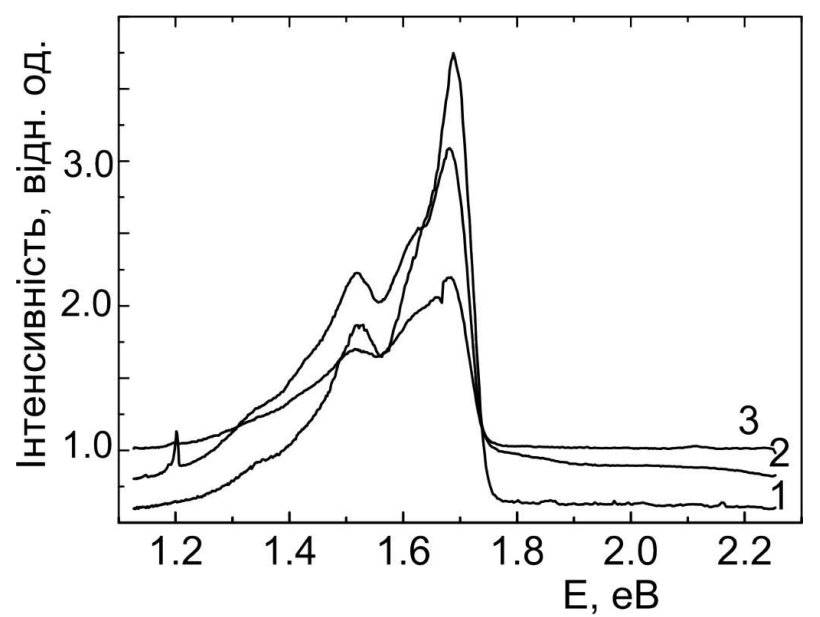

Рис. 7. Спектри фотолюмінесценції для нанокомпозитних плівок $\mathrm{C}_{60}-\mathrm{Cu}$ із вмістом $\mathrm{Cu} 80$ ат.\%

смуги флуоресценції. Таке збільшення триплетного випромінювання вказує на зростання полімеризації в неупорядкованих плівках, яка є наслідком перенесення заряду від атомів міді, що дифундують у гранули $\mathrm{C}_{60}$, до сусідніх молекул і встановлення між ними та атомом хімічної взаємодії.

Іншою є поведінка спектра люмінесценції для плівок з великим вмістом атомів міді (80 ат.\%). Після осадження цей спектр мало відрізняється від спектра, який властивий для плівок чистого $\mathrm{C}_{60} 3$ достатньо вузькими смугами випромінювання флуоресценції і фосфоресценції поблизу енергї 1,69 та 1,5 еВ відповідно, див. рис. 7.

Можна припустити, що у процесі осадження при значній кількості атомів міді відбувається сегрегація фаз з достатньо великими наночастинками обох компонент при малій дифузіі атомів у середовищі $\mathrm{C}_{60}$. Дифузія атомів залишається незначною і при відпалі протягом 10 год, тому спектр фотолюмінесценції порівняно з вихідним змінюється мало. Як і у випадку дослідження спектрів коливання, спектр фотолюмінесценції починає трансформуватися лише за час відпалу 20 год. Видно, що за цей час значно зростає інтенсивність триплетного випромінювання, яка продовжує збільшуватись при 30 год відпалу. Очевидно, що його зростання є наслідком утворення комплексів з металевими атомами за рахунок перенесення заряду від продифундованих атомів до молекул [57-59]. Таким чином, зі збільшенням концентрації осадження атомів металу механізм полімеризації залишається таким же, як і при осадженні меншої кількості атомів міді, але сам процес полімеризації стає більш повільним. 


\section{4. Висновки}

На відміну від легування кристалів або тонких плівок $\mathrm{C}_{60}$ лужними металами 3 низькою енергією когезії, коли наявний однорідний розподіл атомів, розміщених у міжвузлових положеннях гратки, співосадження фулеренів і нелужних металів з високою енергією когезії приводить до формування гетерогенних нанокомпозитів. Вони, залежно від умов співосадження, складаються з відокремлених гранул $\mathrm{C}_{60}$ і атомів металів з різними розмірами та ступенем упорядкування. Така складна морфологія плівок по-різному впливає на їх властивості, які можуть змінюватися залежно від структури одержаних наноматеріалів. Особливістю прояву даної структури є перенесення зарядів від атомів металів до молекул $\mathrm{C}_{60}$, які характеризуються значною енергією спорідненості до електронів як через межу поділу фаз на межі гранул, так i від дифундованих в матрицю $\mathrm{C}_{60}$ атомів металів. Оскільки перенесені заряди локалізуються як на ординарних, так і подвійних зв'язках пентагонів і гексагонів молекул, змінюючи при цьому LUMO \& HOMOстани фулеренів, то вони впливають на стискання й розтягування вказаних зв'язків і, як наслідок, на зміну коливного спектра молекул, в першу чергу, на тангенціальні моди, які стають чутливими до перенесення заряду та структурних ефектів, що з ним пов'язано. Крім того, втілення атомів металів у середовище $\mathrm{C}_{60}$ та встановлення між ними взаємодії сприяє створенню $X$-пасток для синглетних екситонів Френкеля та впливає на квантовий вихід триплетного випромінювання. Вказані фактори суттєво проявляються у трансформації коливних спектрів і спектрів фотолюмінесценції, які змінюються залежно від ймовірності дифузї атомів, яка визначається кількістю осаджених металів, що приходиться на одну молекулу $\mathrm{C}_{60}$, відпалом зразків при підвищених температурах, а також полімеризацією фулеренів за рахунок встановлення хімічної взаємодії між атомами металів і сусідніми молекулами $\mathrm{C}_{60}$.

Так, у співосаджених тонких гранульованих плівках $\mathrm{C}_{60}-\mathrm{Cu}$ із вмістом міді 34 ат.\% вже на стадії осадження спостерігається значне зменшення відносної інтегральної інтенсивності смуги коливної моди $\mathrm{A}_{g}(2)$, а також їі перекривання із сусідньою смугою коливної моди $\mathrm{H}_{g}(7) .3$ відпалом при температурі 473 $\mathrm{K}$ протягом 10, 20, 30 год інтенсивність цієї смуги продовжує зменшуватись, а смуга $\mathrm{H}_{g}(8)$ навпаки зростає, інтегральна інтенсивність останньої вже при відпалі 20 год починає перевищувати аналогічну інтенсивність смуги $\mathrm{A}_{g}(2)$. Зі збільшенням часу відпалу також спостерігається зростання триплетного розсіяння, яке вказує на можливе встановлення взаємодії між молекулами $\mathrm{C}_{60}$ і фулеренами з атомами металів. Оскільки зі зростанням часу відпалу дифузія атомів зростає, то можна припустити, що виникнення хімічної взаємодії між молекулами і атомами є наслідком перенесення зарядів від дифундованих металів до фулеренів. 3 одного боку, така взаємодія може сприяти полімеризації між молекулами $\mathrm{C}_{60}$ за рахунок їх об'єднання атомами металів з утворенням димерів та ланцюгових структур навіть в аморфному стані твердих $\mathrm{C}_{60}$, а з іншого боку, це може приводити до руйнування молекул, про що свідчить зростання інтенсивності смуги $\alpha$-С в інтервалі існування $\mathrm{H}_{g}(8)$ коливної моди.

Для плівок із вмістом міді 80 ат.\% морфологія розподілу та розміри наночастинок міді приводять до підсилення раманівського розсіяння за рахунок сильних локальних полів поверхневих плазмонних резонансів, які виникають у цих наночастинках металу. Зі збільшенням часу відпалу зміни, які відбуваються в спектрах раманівського розсіяння і фотолюмінесценції, аналогічні до їх перетворень в плівках 3 меншим вмістом міді, але вони реалізуються більш повільно. Причиною такого уповільнення процесів полімеризації і руйнування молекул $\mathrm{C}_{60}$ при збереженні механізму цих ефектів є зменшення ймовірності дифузії атомів, яка визначається високою енергією когезії, що наявна при більших розмірах наночастинок, які утворюються для розглянутих плівок.

1. A.M. Rao, P.C. Eklund, J.-L. Hodeau et al., Phys. Rev. B 78, 4766 (1997).

2. V.V. Brazhkin, A.G. Lyapin, S.V. Popova et al., Phys. Rev. B 56, 11465 (1997).

3. В.В. Бражкин, А.Г. Ляпин, Ю.В. Антонов и др., Писъма в ЖКЭТФ 4, 328 (1995).

4. В.В. Бражкин, А.Г. Ляпин, С.В. Попова. ЖЭТФ 11, 755 (1996).

5. В.А. Давыдов, Л.С. Кашеварова, А.В. Рахманина и др., Писъма в ЖЭТФ 10, 778 (1996).

6. А.Г. Ляпин, В.В. Бражкин, Коррелячия физических свойств углеродных фаз, полученных из фуллерита $\mathrm{C}_{60}$ при высоком давлении ФТТ 3, 393 (2002).

7. K.P. Meletov, J. Arvanitidis, S. Assimopoulos et al., Fiz. Tverd. Tela 4, 601 (2002).

8. V.A. Davydov, L.S. Kashevarova, A.V. Rakhmanina et al., Phys. Rev. B 22, 14786 (1998).

9. J. Winter, H. Kuzmany, A. Soldatov et al., Phys. Rev. B 24, 17486 (1996). 
10. P. Zhou, K.-A. Wang, Y. Wang et al., Phys. Rev. B 4, 2595 (1992).

11. G. Dresselhaus, M.S. Dresselhaus, and P.C. Eklund, Phys. Rev. B 12, 6923 (1992).

12. B. Ha, J.H. Rhee, Y. Li et al., Surf. Sci. 3, 186 (2002).

13. A.A. Sabouri-Dodaran, Ch. Bellin, M. Marangolo et al., J. Phys. Chem. Solids 5-6, 1132 (2006).

14. Z.A. Matysina, D.V. Schur, and S.Yu. Zaginaichenko, Carbon 7, 1369 (2003).

15. M. Riccò, T. Shiroka, M. Belli et al., Phys. Rev. B 15, 155437 (2005).

16. T. Shiroka, M. Riccò, F. Barbieri et al., Fiz. Tverd. Tela 3, 498 (2002).

17. S. Saito, K. Umemoto, S.G. Louie et al., Solid State Commun. 5, 335 (2004).

18. A.M. Rao, P. Zhou, K.-A. Wang et.al., Science 259, 955 (1993).

19. G.B. Adams, J.B. Page, O.F. Sankey et al., Phys. Rev. B 23, 17471 (1994).

20. J. Onoe, K. Takeuchi et al., Phys.Rev. Lett. 16, 2987 (1997).

21. J. Onoe, A. Nakao, and K. Takeuchi, Phys. Rev. B 15, 10051 (1997).

22. P.C. Eklund, A.M. Rao, Y. Wang et al., Thin Solid Films 257, 211 (1995).

23. P.C. Eklund, A.M. Rao, P. Zhou et al., Thin Solid Films 257, 185 (1995).

24. Y. Wang, J.M. Holden, A.M. Rao et al., Phys.Rev. B 7, 4547 (1995).

25. J. Onoe, T. Hara, and K. Takeuchi., Synth. Metals 121, 1141 (2001).

26. T.A. Beu, J. Onoe, and A. Hida, Phys. Rev. B 72, 155416 (2005).

27. J. Onoe, T. Nakayama, M. Aono et al., J. Phys. Chem. Solids 65, 343 (2004).

28. A. Takashima, J. Onoe, and T. Nishii, J. Appl. Phys. 108, 033514 (2010).

29. Y. Todaa, S. Ryuzaki, and J. Onoe. Appl. Phys. Lett. 92, 094102 (2008).

30. F.C. Zavisluk, M. Behar, and D. Fink, Phys. Lett. A 226, 217 (1997).

31. K.L. Narayanau, M. Yamaguchi, N. Dharmarasu et al., Phys. Rev. B 178, 301 (2001).

32. R. Kalish, A. Samoiloff, A. Hoffman et al., Phys. Rev. B 24, 18235 (1993).

33. A.I. Ryabenikov, A.V. Petrov, N.M. Polkovnikova et al., Surf. Coat. Technol. 201, 8499 (2007).

34. N. Baiwa, A. Ingals, D.K. Avasthi et al., Nucl. Instrum. Methods Phys. Res. B 212, 233 (2003).
35. K. Narumi, S. Sakai, H. Naramoto et al., Fulleren. Nanotubes Carbon Nanostruct. 14, 429 (2006).

36. C. Ton-That, A.G. Shard, S. Egger et al., Phys. Rev. B 67, 155415 (2003).

37. X. Lu, M. Grobis, K.H. Khoo et al., Phys. Rev. B 70, 115418 (2007).

38. L.-L. Wang and H.-P. Cheng, Phys. Rev. B 69, 045404 (2004).

39. Z. Zhao, H. Wang, B. Wang et al., Phys. Rev. B 65, 235 (2002).

40. Э.М. Шпилевский, Л.В. Баран, Г.П. Окатова и др., Алмазные пленки и пленки родственных материалов (Харьков, 2003), С. 265.

41. Э.М. Шпилевский, Алмазные пленки и пленки родственных материалов (Харьков, 2003), С. 242.

42. M.R.C. Hunt, P. Rudolf, and S. Modesti. Phys. Rev. B 12, 7882 (1997).

43. B.W. Hoogenboom, R. Hesper, L.H. Tjeng et al., Phys. Rev. B 19, 11939 (1998).

44. M.R.C. Hunt, S. Modest et al., Phys. Rev. B 15, 10039 (1995)

45. Z. Zhao, H. Wang, B. Wang et al., Phys. Rev. B 65, 235 (2002).

46. Y. Maruyama, K. Ohno, and Y. Kawazol, Phys. Rev. B 3, 2070 (1995).

47. P. Zhou, K.-A. Wang, Y. Wang et al., Phys. Rev. B 4, 2595 (1992).

48. G. Dresselhaus, M.S. Dresselhaus, and P.C. Eklund, Phys. Rev. B 12, 6923 (1992).

49. A.F. Hebard, R.R. Ruel, and C.B. Eom, Phys. Rev. B 19, 14052 (1996).

50. A.V. Talyzin, U. Jansson, and A.V. Usatov, Fiz. Tverd. Tela 3, 483 (2002).

51. K. Akimoto and K. Kan'no, J. Phys. Soc. Jpn. 2, 630 (2002).

52. D.J. van den Heuvel, I.Y. Chan, E.J.J. Groenen et al., Chem. Phys. Lett. 233, 284 (1995).

53. D.J. van den Heuvel, I.Y. Chan, E.J.J. Groenen et al., Chem. Phys. Lett. 231, 111 (1994).

54. В.А. Карачевцев, А.Ю. Гламазда, В.А. Пашинская и др., ФНТ 8, 923 (2007).

55. V.A. Karachevtsev, P.V. Mateichenko, N.Yu. Nedbailo et al., Carbon 42, 2091 (2004).

56. В.В. Кведер, В.Д. Негрин, Э.А. Штейман и др., ЖЭТФ 2, 734 (1998).

57. T.R. Ohno, Y. Chen, S.E. Harvey et.al., Phys. Rev. B 4, 2389 (1993).

58. B. Morison, Z. Hu, J.P. Jorgensen et al., Phys. Rev. B 9, 6051 (1999). 
59. Ю.В. Шевцов, С.В. Трубин, Ю.В. Шубин и др., Журн. Структ. Химии 45, 77 (2004).

Одержано 30.05.11

\section{ГИБРИДИЗАЦИЯ КОМПОНЕНТ В ТОНКИХ ГРАНУЛИРОВАННЫХ ПЛЕНКАХ НАНОКОМПОЗИТА $\mathrm{C}_{60}-\mathrm{Cu}$}

О.П. Дмитренко, Е.Л. Павленко, Н.П. Кулиш, М.А. Заболотный, Н.Е. Корниенко, В.А. Брусенцов, В.Н. Ръбий, Э.М. Шпилевский

$\mathrm{P}$ е з ю м е

Методом вакуумного совместного осаждения атомов меди и молекул $\mathrm{C}_{60}$ получены тонкие гранулированные пленки нанокомпозита $\mathrm{C}_{60}-\mathrm{Cu}$ с содержанием $\mathrm{Cu} 80$ ат.\%, 34 ат.\% и 8 ат.\%. Эти пленки отжигались при температуре $473 \mathrm{~K}$ на протяжении 10, 20, 30 часов в вакууме. Для пленок с меньшим содержанием атомов меди уже после осаждения наблюдается резкое уменьшение относительной интенсивности и уширение дипольно активной в рамановском рассеянии колебательной моды $\mathrm{A}_{g}(2)$, чувствительной к переносу зарядов от атомов металла к $\mathrm{C}_{60}$. С отжигом уменьшение ее интенсивности сопровождается ростом интенсивности и уширением полосы колебательной моды $\mathrm{H}_{g}(8)$. Кроме того, с отжигом возрастает интенсивность триплетного излучения. Аналогичные процессы, но с опозданием, происходят в гранулированной пленке с большим содержанием атомов меди. Трансформация спектров колебаний и фотолюминесценции указывает на полимеризацию и разрушение молекул $\mathrm{C}_{60}$, которое происходит за счет диффузии атомов меди из гранул в среду $\mathrm{C}_{60}$ с дальнейшим образованием между ними химического взаимодействия за счет переноса зарядов от атомов металла к фуллеренам.

\section{COMPONENT HYBRIDIZATION IN THIN GRANULATED} $\mathrm{C}_{60}-\mathrm{Cu}$ NANOCOMPOSITE FILMS

O.P. Dmytrenko ${ }^{1}$, O.L. Pavlenko ${ }^{1}$, M.P. Kulish ${ }^{1}$, M.A. Zabolotnyi ${ }^{1}$, M.E. Kornienko ${ }^{1}$, V.A. Brusentsov ${ }^{1}$, V.M. Rybii ${ }^{1}$, E.M. Shpilevskyi ${ }^{2}$

${ }^{1}$ Taras Shevchenko National University of Kyiv, Faculty of Physics

(64, Volodymyrska Str., Kyiv, Ukraine),

${ }^{2}$ A.V. Lykov Institute of Heat and Mass Transfer

(15, P. Brovka Str., Minsk BY-220072, Republic of Belarus)

$\mathrm{S}$ u m m a r y

Thin granulated films of $\mathrm{C}_{60}-\mathrm{Cu}$ nanocomposite with the $\mathrm{Cu}$ contents of 80,34 , and 8 at. $\%$ were fabricated with the use of the vacuum codeposition method. The films were annealed at a temperature of $473 \mathrm{~K}$ for 10,20 , and $30 \mathrm{~h}$ in vacuum. Films with lower $\mathrm{Cu}$ contents demonstrated a drastic relative intensity decrease and a broadening of the $\mathrm{A}_{g}(2)$ dipole-active vibrational band in the Raman spectrum, which is sensitive to the charge transfer from metal atoms to $\mathrm{C}_{60}$ molecules. Further annealing was accompanied not only by a decrease of this band intensity, but also by an intensity increase and a broadening of the $\mathrm{H}_{g}(8)$ vibrational mode band. Moreover, annealing gave rise to the growth of the triplet radiation emission intensity. Similar processes, but with some delay, also occurred in a granular film with a higher copper content. The transformation of Raman and photoluminescence spectra evidenced the polymerization and the destruction of $\mathrm{C}_{60}$ molecules owing to the diffusion of copper atoms into $\mathrm{C}_{60}$ crystallites, followed by the chemical interaction between those two components due to the charge transfer from metal atoms to fullerenes. 